\title{
Changing Social Focusing in Indigenous Social Movements
}

\author{
David Flynn \\ Kings University College, London, ON, Canada \\ pdflynn@ rogers.com \\ $\&$ \\ James Hay \\ Western University London, ON, Canada \\ jmh1@ cogeco.ca
}

\begin{abstract}
Using complexity science, we develop a theory to explain why some social movements develop through stages of increasing intensity which we define as an increase in social focusing. We name six such stages of focusing: disintegration, revitalization, religious, organisation, militaristic, and selfimmolation. Our theory uses two variables from the social sciences: differentiation and centrality, where differentiation refers to the internal structure of a social system and centrality measures the variety of incoming information. The ratio of the two, differentiation/centrality (the $\mathrm{d} / \mathrm{c}$ ratio) is a shorthand way of saying that centrality must be matched by a corresponding level of differentiation to maintain basic focusing. If centrality exceeds differentiation, then the result is a lack of focusing-disintegration. On the other hand, the more differentiation exceeds centrality, the more the system moves into the higher stages of social focusing, from revitalization to the final stage of self-immolation. To test the theory we examine historically indigenous social movements, in particular, the Grassy Narrows movement in northern Ontario Canada. We also suggest how the theory might be applied to explain other examples of social movement, especially millenarian movements at the end of the $20^{\text {th }}$ century. We also suggest sociocybernetic ways the rest of society and the social movement itself can change its own social focusing.
\end{abstract}




\section{Introduction}

Social movements are usually evaluated by how they make changes-or resist changes - in society. In this paper, we broaden the definition to include any group of people who are united-we will use the term focused-around an issue. We wish to explain why these movements develop through increasing social focusing as they emerge from disintegration into stages of more coordinated actions, until they become, in some cases, violently militant and even self-destructive. We will suggest an explanation drawn from complexity science.

We will use the example of indigenous social movements (ISM), movement among the original inhabitants of a country. Specifically, we will discuss the Grassy Narrows social movement in northern Ontario, Canada. Our theory of social focusing, however, derived as it is from complexity science, should apply to any social system: from groups, to organisations, to the entire society, although the change from stage to stage may not be as dramatic as in the case of social movements. As well, the degree of social focusing may level off at any point, and not reach the highest extremes.

Beginning with a 'normal' or pre-contact stage for indigenous movements, we will classify the successive stages of increasing social focusing on a trajectory from the disintegration stage of almost no focusing, through what has been termed revitalization movements, to the more intense focusing of new religious movements, then into organisations, culminating in militaristic and movements of self-immolation.

The changes are not inevitable, of course, and we will argue that the extent of the change is related to a theory derived from complexity science (Flynn and Hay, 2012). This theory uses the ratio of differentiation to centrality, abbreviated as the $d / c$ ratio, where differentiation refers to internal structures and centrality to external information flows. The higher the value of $\mathrm{d} / \mathrm{c}$, the more intense the social focusing.

In each of these stages, many other factors are also at work, from charismatic leaders to goals and beliefs specific to each movement, but we hope to show that the $\mathrm{d} / \mathrm{c}$ ratio is a broader, more abstract way to make sense out of the apparently irrational actions of some social movements. The degree of social focusing might, in turn, explain why certain types of leadership and belief structures emerge.

Although we use ISM in this paper, one could easily extend our explanation to premillennium movements at the end of the last century, such as David Koresh's Branch Davidians or James Jones's Jonestown, both of which ended in self-immolation.

We begin with a discussion of the term social focusing. 


\section{The Four States of Social Focusing}

In a recent book, Making Social Change (2012) the authors developed the d/c theory from experiments by Stephen Wolfram with virtual systems, that is, computer models. These computer simulations demonstrate that almost all of the systems he generated could be classified into what he called four classes. The four classes are chaos, complexity and two kinds of order-repetitive and fixed.

Wolfram studied literally millions of virtual systems, beginning with cellular automata (CAs). To illustrate his findings, we will use his results for simple CAs. CAs consist of an initial row of cells which change colour based on certain Boolean rules e.g. if, for a given cell, one of the adjoining cells is white, the cell becomes white at the next step; if both adjoining cells are black, the given cell becomes black. No matter how complicated these virtual systems-two or many dimensions, very complicated connections-the resulting pattern after many steps almost always fell into one of the four classes (Wolfram, 2002: 51ff).

What do these classes look like?

The chaotic class has no obvious pattern, changing over time in unpredictable and undefinable ways. Furthermore, chaos is very sensitive to changes in the initial conditions-the original arrangement of cells.

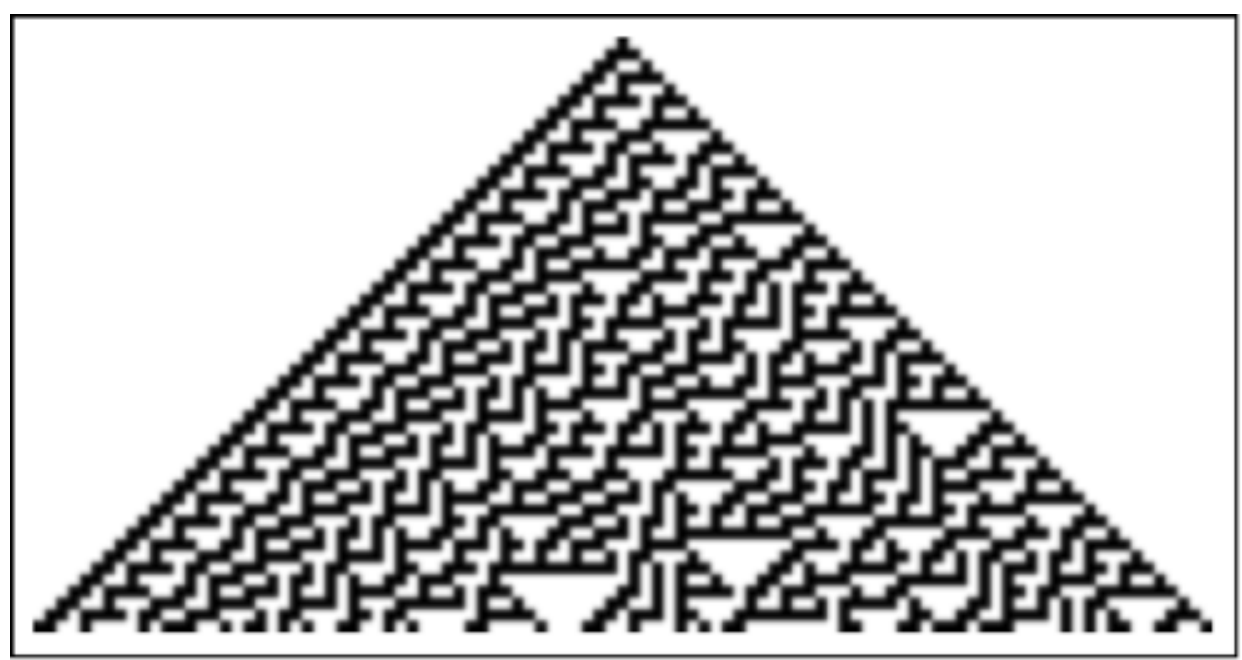

Figure 1: Chaotic Class

The second class, complexity, is a mixture of chaos with some constant ordered patterns. New initial conditions tend to cause only local changes if made in the ordered 
patterns but the system will be very sensitive to changes in initial conditions when those changes are made in the chaotic part of the system.

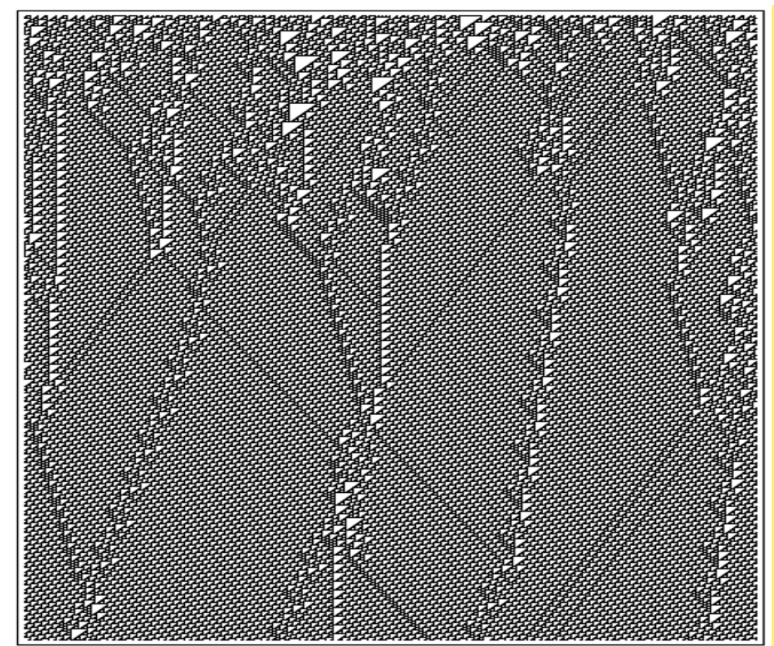

Figure 2: Complex Class

The class of repetitive order is a pattern which repeats over and over, no matter what changes are made in initial conditions.

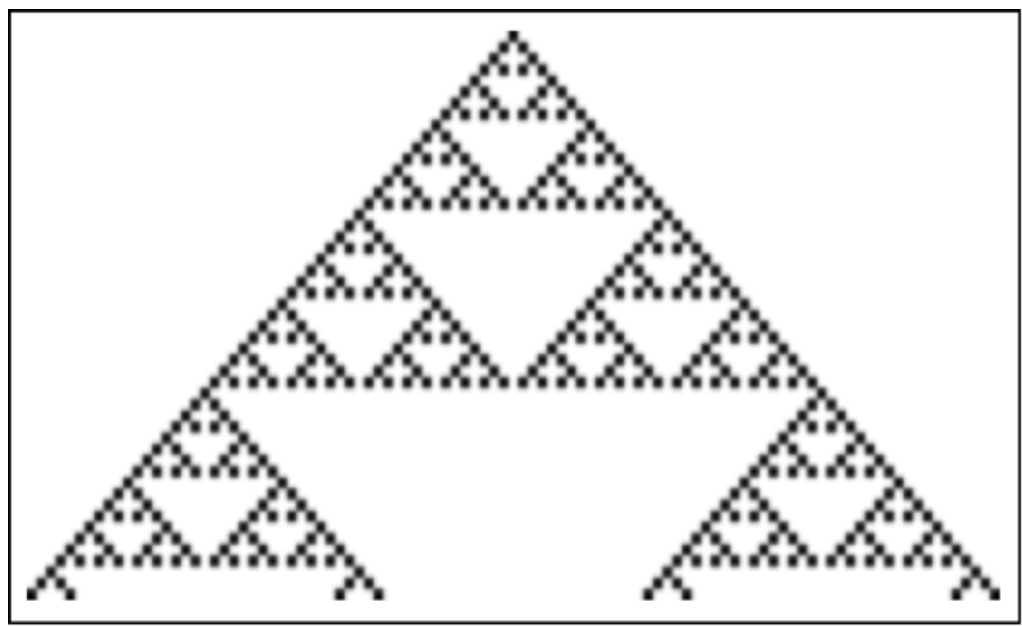

Figure 3: Repetitive Order Class

Fixed order, the fourth class, results in a pattern which never changes no matter what changes are made in initial conditions. 


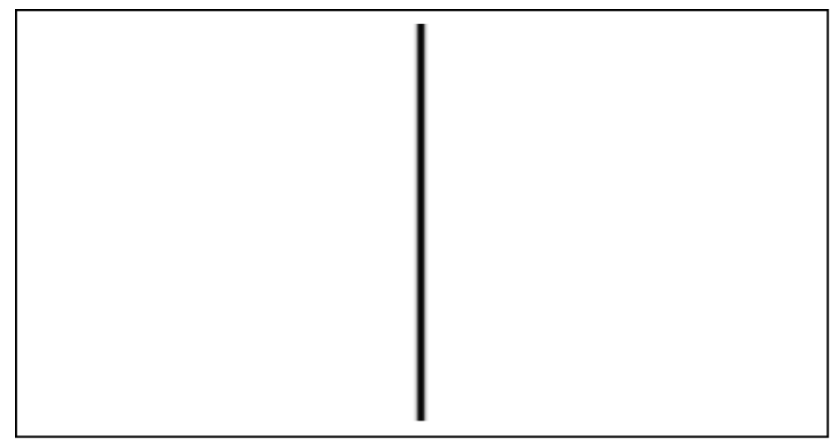

Figure 4: Fixed Order Class

Wolfram's experiments were done with many kinds of discrete systems in addition to simple CAs. By discrete, Wolfram meant that the systems are made up of entities which change in a stepwise process, that is, they are not continuous systems. Since social systems are also discrete, made up of individual human beings who change step by step as a result of their interaction with each other, they are also discrete systems, Hence, Flynn and Hay concluded that social systems must also exist mainly in one of his four classes (2012: 20). To make it clear that we are dealing with social systems, where the term class has a very different meaning, we will use the word state instead of Wolfram's term class to describe the four behaviours of systems generated by social interaction over time.

Flynn and Hay (2012) introduced the concept of social focusing to describe the behaviour of social systems in the fours states. Social focusing is analogous to the light from a flashlight which can vary from almost random flashes to a focused beam.

Chaotically focused systems are like a flashlight which moves around in unpredictable ways. The slightest disturbance moves the light to a different spot. It seems impossible to detect any pattern over time so that descriptions of what transpires become as detailed as the events themselves. We see chaotic focusing when we observe a crowd in a shopping mall milling about.

Ordered focused social systems, at the other end of the focusing scale, do behave in predictable ways. Repetitively Ordered focused systems resemble a flashlight which goes on and off in a steady way which can be summarized in a short formula. Most social organizations are repetitively focused, repeating the same basic procedures over time, described in manuals of regulations and instructions.

Fixed Ordered focused social systems are like a flashlight burning brightly in one direction no matter what happens. Extreme social movements, popularly called cults 
tend to be fixed ordered focused, as they repeat rituals, almost impervious to the influence of outside forces.

Between chaos and order are complex focused systems which have some constant patterns of behaviour, but also have other patterns which change in unpredictable ways, depending upon external influences. Biological evolutions produces systems which are usually complex.

Now, the question of great interest to social scientist: why does social focusing change?.

\section{The D/C Ratio as a Cause of Change in Social Focusing}

What determined which of the four classes resulted from Wolfram's experiments were the initial conditions and the Boolean rule that determined the appearance of the next row. For a given initial condition each rule generated one of the four classes.

Social relationships are controlled by many more rules than even the most complicated virtual systems Wolfram modelled. As well, social systems are more open to external influences than a computer model so that there are many factors which affect the behavioural state of a system. Wolfram and others have discovered that it is essentially impossible to predict the class of even the simplest CA without actually running the system, so it is obviously impossible to predict the state of even the most simple social group based on the knowledge of initial conditions and rules of interaction.

Flynn and Hay developed another approach to predict the state of social systems' focusing: the relationship between two social variables, differentiation and centrality (2012: 31ff). Differentiation refers to the internal structure of the system and corresponds to the rules in a CA, although much more complicated. Centrality is the input of new information coming into the system. For a CA this would be represented by the initial conditions at any one time.

Flynn and Hay discussed a variety of ways for measuring differentiation and centrality. They broke down the variable of differentiation into four parameters described by Scott Page (Page, 2009). The four Page parameters are diversity, connectedness, interdependence and adaptability (Flynn and Hay, 2012: 32-41). In brief, then, differentiation is measured by the variety of subsystems as well as the manner in which those subsystems are connected through varying amounts of mutual dependence, along with their ability to adapt to each other. A crude but fast way to estimate differentiation is to do a simple count of the number of different subsystems. 
Centrality, the variety of outside information entering the system, also can be measured in many ways (Faust and Wasserman, 1992). Again, a simple way to measure centrality is just to count the number of links to other systems. This indicator assumes that each of the linked outside systems contributes the same amount of new information.

Flynn and Hay then used Ashby's Law of Requisite Variety (Ashby, 1966 (1956)), and Young's discussion of community solidarity (Young and Young, 1973) to argue that the degree of social focusing is related to the ratio of differentiation to centrality, the $\mathrm{d} / \mathrm{c}$ ratio. That is, the higher the level of centrality - more incoming information - the more chaotic is the system since the new information tends to disrupt the system's focusing. Higher centrality means a lower $\mathrm{d} / \mathrm{c}$ ratio, if differentiation remains constant, hence less focusing.

On the other hand, more ordered focusing is directly related to increasing differentiation, since the more varied and the more interrelated the parts, the more able is the system to cope with new information. Higher differentiation raises the $d / c$ ratio, as long as centrality is constant, and so produces more order.

In general, then, when the ratio is very low, that is, differentiation is much less than centrality, the system will be in a state of chaos. At the other extreme, when the ratio is quite high-differentiation is much greater than centrality - the social system will be in one of the two ordered states. Around the point where the two variables are equal, systems will be in the complex state, a mixture of chaos and order, what early complexity scientists called the edge of chaos.

Again, there may be many factors affecting the social focusing of social systems, but the $d / c$ ratio represents an underlying causal relationship which we will use to study social movements.

\section{Social Focusing in Indigenous Social Movements}

The Table below lists seven types of ISM. The names of the seven types are drawn mainly from the terminology used in the description of indigenous movements. Although we have arranged them in the order in which many ISM develop over time, not all ISM evolve into the higher stages. The actual stage depends, we argue, primarily upon the $d / c$ ratio. 
Table 1: Stages of indigenous social systems, level of social focusing, and the $d / c$ ratio

\begin{tabular}{|c|c|c|}
\hline Stages of ISM & Social Focusing & D/C Ratio \\
\hline 1. Pre-Contact & Repetitive Ordered & $\mathrm{d}>\mathrm{c}$ \\
\hline 2. Disintegration & Chaotic & $\mathrm{d}<\mathrm{c}$ \\
\hline 3. Revitalisation & Complex & $\mathrm{d}=\mathrm{c}$ \\
\hline 4. New Religious & Complex & $\mathrm{d}=\mathrm{c}$ \\
\hline 5. Organisation & Repetitive Ordered & $\mathrm{d}>\mathrm{c}$ \\
\hline 6. Militaristic & Repetitive ordered & $\mathrm{d}>>\mathrm{c}$ \\
\hline 7. Self-immolation & Fixed Ordered & $\mathrm{d}>>>\mathrm{c}$ \\
\hline
\end{tabular}

In the first column we use the terms of social focusing, beginning with 'normal' focusing before outside contact, and ending with the rarely seen and fatal self-immolation stage. In the second column we classify each stage in terms of focusing, ranging from chaos to order. Finally, in the third column, we suggest how the $d / c$ ratio affects the stage of focusing for an ISM.

The seven types of indigenous social systems are discussed in more detail in the following sections, illustrated with general descriptions of what has happened in indigenous communities, mainly in Canada, before and after their contact with European cultures. We then will present the case study of the Ojibwa First Nation of Grassy Narrows.

\subsection{Stage One: Pre-Contact}

The term pre-contact for North American indigenous groups refers, of course, to the time before contact with Europeans. Since pre-contact historical records are scarce, we use oral history which indicates that there were social movements before the time of Europeans, as indigenous groups invaded each other's territory. Still, we can assume that most of the time indigenous tribes were in a state of relative calm, a 'normal' state 
of repetitive ordered focusing, typical of organisations (2012: 54). We are naming this stage pre-contact.

Most pre-contact indigenous groups were relatively isolated, that is, had low centrality, with enough internal differentiation to keep them within a state of order where patterns were repeated.. In such a state they could handle external changes such as environmental variety (centrality) due to seasonal fluctuations and even occasional food shortages, so that they could satisfy their basic needs, a production system marked by repeated rituals and behaviours. As well, each group had a great enough variety of differentiated weapons to cope efficiently with the sometime spikes in centrality caused by threats from other tribes.

If too threatened by higher centrality - attacks - which they could not handle, some groups organized a defensive suprasystems with other tribes to reduce threats. A good example was the Confederacy of the Six Nations tribes, which added varietydifferentiation - to keep the $\mathrm{d} / \mathrm{c}$ ratio higher than outside centrality.

Other tribes just moved away when attacked, thus keeping centrality lower than differentiation and restoring the $\mathrm{d} / \mathrm{c}$ ratio. This was the strategy of the Ojibwa, the tribe of Grassy Narrows, when the Six Nations Confederacy invaded their territory (Warren, 1984(1885)).

\section{Grassy Narrows: Pre-Contact}

The people of Grassy Narrows at the time of European contact, formed a small group located on islands in a marshy area about $100 \mathrm{~km}$ north of the present city of Kenora in northern Ontario. They were part of a larger indigenous group, the Anishnabek, more commonly known as the Ojibwa. Early Ojibwa myths describe a time of living near a great body of water. Most likely the legends refer to the Great Lakes, in the lands of the Six Nations (Warren, 1984(1885)).

At the time of the first French contact in 1623, the Ojibwa had relatively low differentiation, specialised almost exclusively in hunting and fishing. Unlike the Six Nations group in the fertile lands around the lower Great Lakes, Ojibwa lands could not support farming so the Ojibwa did not have a variety of differentiated agricultural skills.

Major problems of survival for indigenous groups began when they were threatened by a much more differentiated system such as happened to the Ojibwa after Europeans began to settle Canada from the seventeenth century on.

\subsection{Stage Two: Disintegration}

We are using the term disintegration to describe the second stage of social movements, especially indigenous ones, where social focusing descends into chaos. As used here, 
disintegration refers to a phase that involves various forms of inward directed violence-substance abuse, family violence, homicide and suicide. It is the initial reaction of a social system when its centrality suddenly increases to very high levels because of contact with a much more differentiated system, resulting in a very low $\mathrm{d} / \mathrm{c}$ ratio. It is the chaos which occurs when a social system collapses from the impact of outside information. It is the behaviour of a system which has lost focusing.

The Royal Commission on Aboriginal Peoples (RCAP) was set up by the Canadian government in the early 1990s shortly after armed confrontations between government authorities and several indigenous militaristic movements-which we discuss later in this paper (Canada, 1996). The Commission devoted a special volume of its report to a study of suicide among indigenous groups. They compared high indigenous suicide rates to non-indigenous rates, noting as well high rates of other kinds of violence and concluded that violence in one form or another was the leading cause of death among indigenous people in Canada.
...the conclusion is inescapable that Aboriginal people are more likely to end their own lives prematurely - to kill themselves - than non-Aboriginal Canadians. They are also more likely to die from other forms of violence. According to Health and Welfare Canada, the leading cause of death among 'registered Indians', measured over all age groups, is injury. This is the mortality grouping that includes accidental death as well as homicide and suicide. By comparison, in the Canadian population as a whole, injury is only the fourth leading cause of death... (Canada, 1995: 17).

Disintegration is what happens when the traditional tribal structure of pre-contact indigenous people is simply overwhelmed by the variety of new weapons, demands and technology of outsiders. The invaders also bring new diseases and toxic substances such as alcohol, for which, again, the tribes have insufficient defences. It is as though the power and strength of tribal members which, in the past, would have been used to ward off threats from the surrounding environment, including other tribes, is turned inward, with both personal and social damage. Examples of the personal impact of disintegration are suicide and substance abuse. Social impacts of disintegration include injury to others and homicide, as well as spouse and child abuse.

There are a host of additional variables contributing to these problems, for both indigenous and non-indigenous alike, including demographic factors-indigenous groups in Canada, for example, have a higher proportion of younger people who, in all populations, are more likely to be involved in violence (Canada, 1995: 122, fn 127). Furthermore, as with all chaotic processes, there are feedback loops which cause an interaction among the problems in ways too complex to unravel in a simple, linear cause and effect model. For example, addiction to alcohol may lead to child abuse which, in turn may cause violent behaviour and drinking among young males, and the 
cycle escalates. Nevertheless, we believe that the very low $\mathrm{d} / \mathrm{c}$ ratio provides an overall explanation which cuts across the entire process, and we are suggesting that an understanding of social focusing and its relationship to the $d / c$ ratio contributes to a broad, and, hopefully, useful approach to the problems of disintegration.

One solution recommended by RCAP is consistent with the low $\mathrm{d} / \mathrm{c}$ ratio This solution involves various self-help programmes and especially increased education and training to raise the level of differentiation in the form of "...basic living/social skills..." (Dolha, 2003: 7).

As well, RCAP praised youth centres which provide a "vital weave of support" (Canada, 1996: 2). In effect, the Centres are helping to close off contact with outsiders in order to decrease centrality as a defence against the dominant culture. They are a more healthy replacement for youth gangs, and a modern equivalent of the traditional, now destroyed, networks of social focussing which used to exist.

Another way of raising differentiation is the development of indigenous professionals "...each with their own area of expertise in business, program development and crime prevention." These professionals not only represent higher differentiation for all their people, but through their programmes they increase differentiation in the community. In addition, these professionals help foster local organisations, again an alternative to gangs. The revival of traditional religion also represents a significant sign of higher social focusing which we will explore later in our discussion of revitalisation and religious social movements.

Disintegration, then, appears among a group of people that has insufficient differentiation to handle the impact of centrality inputs from outsiders. The result is a variety of social problems, from suicide to homicide as the cultural mores crumble under the impact of information overload.

\section{Grassy Narrows: Disintegration}

This small Ojibwa community-now just under 100 people who live there and another 500 who live in the area-has become one of the most dramatic case studies on the consequences of a rapid increase in centrality without a matching increase in differentiation. These consequences are described vividly in Shkilnyk's A Poison Stronger than Love where she looks at what happened when residents between 1963 and 1972 were relocated from a place of relative isolation to a road which connected the community to the city of Kenora, $100 \mathrm{~km}$ to the south (Shkilnyk, 1985: 1). (All page numbers in this section, unless otherwise noted, are from Shkilnyk's book.)

Over the two decades following the relocation, the community fell apart, with appalling levels of suicide, violence and substance abuse. Consistent with our 
terminology, Shkilnyk uses terms such as 'disintegration' and 'chaos' to describe the results.
The pattern of deaths over the past twenty years leaves no doubt that violent death is a recent phenomenon at Grassy Narrows, associated with the move to the new reserve in the mid-1960s. Prior to the relocation, in the period 1959-63, 91 per cent of all deaths in the community were due to natural causes. By the mid-1970s, only 23 per cent of all deaths could be traced to old age, illness, or accident...During 1974, 75 per cent of all deaths were due to alcohol or drug-induced violence directed against others or against the self (pp. 12,13).

In Grassy Narrows between 1969 and 1976, more than half (52.4\%) of all deaths were violence of one kind or another: suicide, homicide or substance abuse (p. 13). Shkilnyk summarises these statistics in words which are almost a definition of disintegration:

In this community, people have turned their anger inward, lashing out against those closest to them or against themselves (p. 6).

The story of Grassy Narrows is complicated by a major environmental disaster which occurred during the move to the Kenora road. From 1962 to 1970, Reed Paper, a pulp and paper mill dumped over 20,000 pounds of mercury upstream from the community (p. 32). Mercury levels in the Wabigoon-English River systems were lower than the levels found at Minamata, Japan, from which the syndrome associated with mercury poisoning acquired its name. The levels, however, were above the recommended levels, and there was undoubtedly some physical impact on residents. The problem is, some of the symptoms - trembling, numbness, apathy - are also associated with alcohol abuse.

More significant, the residents saw the mercury spill as one more attack on them against which they had no defence. Perhaps the greatest impact was the closing of their rivers to fishing in 1970 because of the mercury contamination. Residents had depended upon fishing for food and for income from sport guiding. As Shkilnyk puts it, quoting local people, "this was 'the last nail in the coffin"” (p. 181).

Finally, after years of negotiation, Grassy Narrows and another affected First Nation received \$12 million direct compensation from the Federal and Provincial governments and the paper company, along with the establishment of a Mercury Disability Board to handle future physical effects (Canada, 1986). Long before this settlement, the community suffered, and in response moved into higher levels of their social movement.

The good news for all indigenous communities in Canada, and Grassy Narrows in particular, is that most are slowly moving out of disintegration and becoming more focused. One indirect measure of community health which combines social focus and differentiation is the United Nations' 'Human Development Index' which combines per capita income, life expectancy and education. On this measure, Canada is ranked number one, while indigenous Reserves are $68^{\text {th }}$ in the world, but the gap between indigenous and non-indigenous Canadians has steadily narrowed over the period 1981- 
1996 (Roberge, 2002). If social systems can raise the $\mathrm{d} / \mathrm{c}$ ratio out of disintegration they may move on to the first real stage of a social movement, into the revitalization and religious movement stages, and a recovery of traditional focusing.

\subsection{Stages Three and Four: Revitalization and Religious Movements}

As long as outside centrality exceeds internal differentiation, disintegration is likely to continue with all of its devastating consequences. Over time, however, Flynn \& Hay predict that a social system will increase its differentiation capability to meet the impact of the high outside centrality (2012: 24ff).

For indigenous communities this will move the group out of chaos into the complex region at the edge of chaos. This state would correspond to what anthropologists term a revitalisation or religious movement. When the movement is complex focused, people feel a renewed sense of identity and power as the group revives old traditions and religious beliefs, and a new kind of community emerges.

The term "revitalisation movement" comes from Anthony Wallace's classic paper, and later book, on the movement started at the end of the 19th century by the prophet Handsome Lake among the indigenous Senecas, one of the Six Nations living in upper New York State (Wallace, 1956; Wallace, 1972(1969)). Handsome Lake's revitalization movement merged cultural revival with religious revelation, and this combination of revitalisation and religion is not unusual in indigenous movements when differentiation and centrality are closely matched. Nevertheless, we believe there is some merit in separating the two types since we see religious revival as more intense, more emotional, more focused than revitalisation alone.

The movement at this stage is often led by a leader with charisma, such as Handsome Lake, a person who can demonstrate these traditional strengths personally. Often the leader has experienced recovery from a personal problem such as heavy drinking associated with the disintegration phase. The successful leader during this phase will select certain traditions as especially helpful in the new world constructed by the outside culture. For example, the leader will point out that behaviours such as working together as a tribe, and sharing money and effort were typical among indigenous people before the Europeans came. Unlike the surrounding modern culture with its emphasis on competition, individual success and the accumulation of wealth, indigenous movements argue that their traditional morality put more emphasise on group cooperation, sharing and equality. Such practices also happen to be useful for tribes who need to co-operate in order to raise themselves out of poverty.

As with the Handsome Lake movement, there may be a religious overtones as the charismatic leader becomes a prophet who appeals to God-given guidance for following 
this particular path. At the same time, the movement may develop in unexpected directions, as we might expect during complex focusing. Interestingly enough, this backward turning in order to move forward, is often recalled later as a wonderful time when an almost magical spirit moved people in a miraculous way, not unlike the sense of wonder experienced by sports teams after a game played in the Zone (Flynn and Hay, 2012: 99ff).

When revitalisation movements are combined with religion, followers become disciples of the one true group, often wearing special garments and using sacred rituals and words. The nineteenth century Ghost Dances among Northwestern American indigenous tribes are perhaps the best known example of indigenous social movements which combine revitalization and religion (Kehoe, 1989; Shiell, 1990).

In the next section we look at what is happening in Grassy Narrows as it begins to recover from the horrors of disintegration, and finds more focusing at the edge of chaos. Again, page numbers refer to Shkilnyk (Shkilnyk, 1985).

\section{Grassy Narrows: Revitalisation/Religious Movement}

The only known religious social movement among the Ojibwa was the Midewiwin Society. Although there is much controversy about the origins of the Midewiwin religious movement, most scholars agree that

...the Midewiwin was a nativistic movement, or "crisis cult," which emerged in

reaction to European contact (Angel, 2002: 10).

The Midewiwin movement began during the late $18^{\text {th }}$ century soon after the arrival of Europeans. It thrived most among the more isolated groups in the middle of the continent, where centrality was lower (Angel, 2002: 122-123). It reappeared in the 1970s and 1980s among more educated Ojibwa (Angel, 2002: 174). Shkilnyk notes that before the relocation, when Grassy Narrows was more isolated-with lower centrality and, hence, higher $\mathrm{d} / \mathrm{c}$ - there were Midewiwin ceremonies in Grassy Narrows (p. 249n4).

Certainly, during the recent crisis period, $\mathrm{d} / \mathrm{c}$ was very low so we would expect little evidence of a religious movement and Shkilnyk found no evidence for it when she was there, even during the later phase of recovery from the chaotic period of disintegration, but she points out that because the Midewiwin was a secret society, outsiders might not be aware of its revival.

In any case, Grassy Narrows may have gone through its revitalisation and religious phase fairly quickly after the community began to emerge from disintegration. Hence, Grassy Narrows seems to have evolved quickly into an organisational and then a militaristic phase, characteristic of Stages Five and Six. 


\subsection{Stage Five: Organisational Social Movement}

Organisations, according to Flynn \& Hay, are repetitive order focused, because differentiation is sufficiently higher than centrality (2012: 63ff). During this stage we would expect several, even many hubs, each with some autonomy but connected enough to other hubs to ensure repeated routines (2012: 36-37, 116).

As we mentioned earlier, during the pre-contact period, indigenous groups were usually in this organisational stage, with each clan or even extended family acting as a hub controlled by a chief or leader, with some sort of hierarchy reporting to him or her. As well, there is a loose network connecting the clans and family hubs, just what we would expect during repetitive ordered focusing.

The group has developed sufficiently high differentiation to deal with the influx of centrality. Good examples of successful and prosperous indigenous organisations in North America are ones with high oil revenues such as the Comanche of Oklahoma, or those who border large cities, as is the case with the Bloods First Nation near Calgary. Their organisations resemble a large corporations, with highly skilled experts working in different departments.

If, on the other hand, discrimination and exploitation from the outside become worse, that is, people are not treated with respect by the rest of society, this lower centrality combined with the higher differentiation from education and training will lead to even higher social focusing, the kind found in the next stage, a militaristic social movements, as the $\mathrm{d} / \mathrm{c}$ ratio rises.

Before moving to that higher stage, let's look at what happened in Grassy Narrow during the organisational stage.

\section{Grassy Narrows Organisational Social Movement}

As with other American indigenous tribes before contact, there were several chiefs for different purposes among the Ojibwa. Each clan had its own leader as did each family. Yet the entire social system of Grassy Narrows was bound by loose ties which were reinforced during the times of gathering, during spring fishing, for example.

Quite likely Grassy Narrows would be an organisation today, as many First Nations have become, if they had been treated fairly by outsiders, especially pulp and paper producing companies and the government. They could have used the revenue from the Mercury poisoning settlement, combined with royalties for selected forest harvestingwhich they did not receive-along with income from fishing and hunting - destroyed by the mercury spills - to become reasonably prosperous. This may still happen in the future. For the moment, however, Grassy Narrows, in response to the denial of their 
economic rights, has moved past the organisational stage to become a very militant social movement.

\subsection{Stage Six: Militaristic Social Movements}

Militaristic movements have the fanatical fervour of revitalisation and religious movements but with more discipline and more hierarchical control. They have moved from repetitive to fixed ordered focusing because even though their level of differentiation has increased, they are denied equal access-centrality-to the rest of society so $\mathrm{d} / \mathrm{c}$ rises and the increased social focusing takes the form of a militaristic movement.

Armed with a revived cultural identity from the revitalisation stage, and with a sacred confidence in the rightness of its actions from religious inspiration, the group responds to suppression with military force. The leader becomes an army general who, along with the followers, often wears a uniform so that the group literally has a uniform appearance, typical of fixed focusing.

If the outsiders are too well armed for the social movement to attack directly, the group may turn to guerrilla tactics, raids, vandalism and other forms of illegitimate-as perceived by the outsiders-behaviour to try to destroy what they perceive as the enemy. It may seem hopeless but often the violence triggers negotiation, the first step toward a settlement which should lead to higher access-centrality-for the tribe and a possible move back into organised repetitively focused order.

The Ojibwa of Grassy Narrows are a good illustration of the shift to a quite militantly focused social movement.

\section{Grassy Narrows Militaristic Social Movement}

Although Grassy Narrows first became international news as an extreme example of disintegration, the original Ojibwa have a long history of successful military resistance to European pressure. Constantly fleeing ahead of the invaders from other indigenous groups such as the Iroquois of the Six Nations, the Ojibwa kept their centrality very low for most of their history. They were also well armed by the French, the main rival to the British in North America. They used these weapons to run up a remarkable series of military successes. To quote one writer, describing the last official battle of the American "Indian Wars", in 1898,

...as was the case with almost every enemy they had ever faced, the Ojibwe won the battle (Sultzman, 2000: 42).

A military phase for Grassy Narrows began in 1999 in response to continued clearcutting of timber on traditional Grassy Narrows lands. The loggers worked for Abitibi- 
Consolidated, at that time the world's largest manufacturer of newsprint (Clarke, Clarke et al., 2003: 3). Although the clear-cutting had begun in the 1950s, it accelerated in the 1990s. The protest consisted of Grassy Narrows' people hanging painted signs near roads leading into the clear-cutting area "declaring [Grassy Narrows ] land rights" (Fobister, 1999).

This action came after three years of meetings by community members in cities across the country which was a way to increase differentiation among Grassy Narrows residents by increase their repertoire of actions, although it also increased slightly their centrality. The initial posting of signs seems to have had little effect until December, 2002 when residents began hanging the signs on chains across the roads, thus setting up blockades, and confronting Abitibi equipment attempting to enter the area. It is interesting that this action began when a trapper, Joe Fobister, asked school children, the more differentiated segment of Grassy Narrows society, if they would help stop Abitibi, and the children suggested actual barricades. Eventually the children were supported by the Elders and assisted by several other groups, including members of the Ogitchiidaa Warrior Society (Clarke, Clarke et al., 2003).

The trigger for the physical blockade of access roads was the announcement-not a proposal-in 2002 of a twenty year Whiskey Jack Management Plan between AbitibiConsolidated and the provincial government. The assumption behind the Plan was that this forest land was Crown land, hence, while the Ojibwa First Nations people were asked to comment, along with other people who might be affected, they did not have a veto.

The Ojibwa disagreed with this assumption, arguing that the decision was in violation of Treaty \#3 signed in 1873, by which the Ojibwa people turned over this land to the Crown but in return were guaranteed certain "traditional land uses", including hunting and fishing (Fobister, 1999; Carter, 2003: 3; Tabar, 2005). Not surprisingly, the residents of Grassy Narrows believed that clear-cutting of the forest would affect their traditional hunting and fishing activities.

At the moment, there is no agreement on the use of Grassy Narrows' traditional lands, although Abitibi-Consolidated in 2004 proposed a new, shorter-term plan for the management of forests in the area. Grassy Narrows residents boycotted discussion of the new plan, arguing that in the past when they attempted to use organisational approaches of discussion, no matter what they recommended, the clear-cutting went on (macho, 2005).

In early 2007, Abitibi merged with another pulp and paper company, Bowater, but by 2009 had filed for bankruptcy protection. The misfortunes of Abitibi go far beyond the Grassy Narrows Blockade - there is a general slump in the sale of newsprint-but the 
publicity over Grassy Narrows cut down on sales of Atitibi newsprint, especially in the US (Knudson, 2003).

In mid 2011, the Ontario Supreme Court ruled that the province cannot authorize logging on Crown Land if it infringes on indigenous Treaty rights. Recently, in September, 2013, the provincial government announced they would appeal the Ontario Court decision to the Supreme Court of Canada (CanPress, 2013). Meanwhile, after more than a decade of militaristic resistance, the clear-cut logging continues as logging companies sneak onto the land by building other, more remote roads.

However, the good news is that negotiations have started between the Ojibwa and the Provincial government on ways to improve conditions-and make up for past failures. Grassy Narrows has come a long way.

The final stage-literally-for a few social movements is the stage we call selfimmolation, where the group dies through mass suicide. Fortunately, there is no sign that Grassy Narrows has ever come close to this intense phase of focusing.

\subsection{Stage Seven: Self-immolation Movements}

The self-immolation social movement, where a group decides to die together, is the least understood type. Self-immolation goes back in recorded history at least to 73 C.E. when a group of about a thousand members of a Jewish militaristic movement chose mass suicide rather than submit to capture by the Romans(Greenberg, 2005). Over the centuries other beleaguered people have chosen death over humiliation and persecution. The most famous modern examples have to do with Millenarian cults such as the ones led by The Reverend James Jones whose followers committed mass suicide in 1978, and the Branch Davidians, under David Koresh, who died together in 1993.

We believe self-immolation is at the upper limits of social focusing. Yet the outcome seems to go against the assumption that survival is built into all evolved living systems. But for members of such extreme religious social movements, death is a step toward a new life in the next world. Self-immolation represents very high fixed ordered focusing, where all members are focused on the same goals and a common outcome. In Jonestown members rehearsed their final moments to make sure no one deviated.

To achieve this intense kind of social focusing, the $\mathrm{d} / \mathrm{c}$ ratio must be very high. Both the People's Temple and the Branch Davidians were quite differentiated, with a variety of skills. More significant, centrality was very low. In the case of the Branch Davidians, the Bureau of Alcohol and Tobacco and then the FBI steadily closed in on the compound, cutting members off from outside contact. Significantly, their leader, David Koresh's main request to the Bureau was the opportunity to present his side to the media. The request was denied. In the end, 
...the destruction of their compound by tanks seems to have changed their calculus dramatically toward a choice they were prepared to take: self-immolation over surrender (

Any indigenous group which challenges a modern army risks death - a recent Canadian example was the standoff at Kanehsatake, Quebec in 1990. One soldier was shot and if tribal members (encouraged by members of AIM, the American Indian Movement) had escalated the violence, many local people would have died. After tense negotiations, some of the outstanding issues were resolved and the standoff ended peacefully. In part, this was because, unlike the Branch Davidians face-off, the media did have access to both sides, and people could, with difficulty, move in and out of the community. We would argue that very tight restraints around an ISM may cause mass suicide, if the $d / c$ ratio is sufficiently large.

Self-immolation seems similar, on the surface, to disintegration where violence is turned inward. The difference is that self-immolating groups have already passed through the earlier stages and are now united in a desire to die together. In contrast to disintegration, where the members blame each other for their suffering, in the selfimmolation type they know the enemy is out there. In full awareness, they choose mutual death over surrender.

\section{Grassy Narrows: Self-Immolation}

There are no signs of mass suicide among the people of Grassy Narrows. That is probably a reflection of their success in capturing world attention, and winning their most recent court case, that is, their centrality is rising to catch up with their education and skills.

\section{Conclusion}

Earlier chroniclers of social movements among indigenous people, have suggested that these movements develop along a certain trajectory from initial contact to eventual adaptation and even assimilation (Wallace, 1972(1969)). Drawing on chaos and complexity science, we are suggesting that this path is related to a movement along the axis from chaos to order, with a midpoint of complexity (Wolfram, 2002). To put it another way, social systems which are chaotic have a very low amount of social focusing, while ordered systems are very focused, and complex systems are in between. Our explanation for these transitions from low social focusing to high focusing comes from the relationship between two sociological variables, differentiation and centrality, which can also be related to complexity science (Flynn and Hay, 2012). Differentiation represents the internal variety and structure used by social systems to cope with outside 
information. The variety of that outside information is identified as the level of centrality. The ratio of these two variables, the $\mathrm{d} / \mathrm{c}$ ratio, we argue, explains why social focusing varies. The higher the ratio, the more focused the system.

In this paper we have applied this theory to explain why there are different types of indigenous social movements. Following a more or less ordered community during the pre-contact period, there is an initial stage of chaotic disruption because the invaders introduce too much information-higher centrality-for the tribes' level of differentiation and the $\mathrm{d} / \mathrm{c}$ ratio falls. As social focusing increases in response to a higher $\mathrm{d} / \mathrm{c}$ ratio-usually because differentiation-education-rises, ISM become complex focused as revitalisation movements. Revitalization means a return to past tradition. Such revitalized groups may also focus around the divine inspiration of a religious movement and a prophet.

At this point, if differentiation continues to rise, the indigenous movement will become an organisation-repetitive ordered focused—sometimes literally incorporating as a business..

If, however, differentiated skills develop without a corresponding access to jobs and power-centrality remains low-then the surge in the $d / c$ ratio pushes the group into a militaristic movement which attacks those who are denying access. At the most extreme level of $\mathrm{d} / \mathrm{c}$, the result is a self-immolation movement of mass suicide.

Throughout this paper, we have alluded to other kinds of social movements among non-indigenous groups such as the extreme religious movements at the end of the last century, some of which did end in mass suicide. The $d / c$ ratio could also be used to interpret the actions of contemporary social movements such as the environmental movements, the Occupy movement or social movements among Moslem groups.

There are policy implications for both the larger society and for members of sociocybernetic movements themselves. For authorities, attempts to suppress, that is lower the centrality of the social movement will only increase the fervour, perhaps to dangerous levels. Education of members will also increase social focusing unless society is prepared to open up opportunities-increase centrality-for those who are now more differentiated.

Social movements themselves can use the $d / c$ ratio to increase their focus by limiting access from outsiders, thus lowering centrality. The same increase in focusing will happen if members acquire more skills. These are good strategies for generating a social movement which can pull itself out of the morass of disintegration.

We are optimistic that, at least for the indigenous residents of Canada, the centrality levels are beginning to match their differentiation. We would expect, then, that in the future more Canadian ISM will evolve into organizations. 


\section{References}

Angel, M. (2002). Historical perspectives on the Ojibwa Midewiwin: Preserving the sacred. Winnipeg, The University of Manitoba Press.

Ashby, W. R. (1966). An introduction to cybernetics. New York, John Wiley.

Canada (1986). Grassy Narrows and Islington Indian Bands Mercury Pollution Claims Settlement Act. Ottawa, Government of Canada.

Canada (1995). Choosing life: Special report on suicide among aboriginal people.

Canada (1996). Report of the Royal Commission on Aboriginal Peoples. Ottawa.

CanPress (2013). Supreme Court to hear Grassy Narrows' challenge over logging. The Globe and Mail Online. Toronto.

Carter, L. (2003). Grassy Narrows fights for their future. First Nations Drum. Toronto.

Clarke, L., J. Clarke, et al. (2003). "Asubpeeschoseewagong degation report." Retrieved April 27, 2005, from http://www.cpt.org/delegations/asubdelrpt.php.

Dolha, L. (2003). Aboriginal gangs in prairie provinces in "crisis proportions". First Nations Drum: $1-8$.

Faust, K. and S. Wasserman (1992). "Centrality and Prestige: A Review and Synthesis." Journal of Quantitative Anthropology.

Flynn, D. and J. Hay (2012). Making Social Change. Sarnia, Ontario, Grafiks Marketing \& Communications.

Fobister, W. (1999). "A message from chief William Fobister." Retrieved April 27, 2005.

Greenberg, I. (2005, 2005). "Masada: Desert Fortress overlooking the Dead Sea." Retrieved April 28, 2005, from http://www.jewishvirtuallibrary.org/jsource/Archaeology/Masada1.html.

Hall, J. R. (2000). Apocalypse observed: Religious movements and violence in North America, Europe, and Japan. New Youk, Routledge.

Kehoe, A. B. (1989). The Ghost Dance: Ethnohistory and Revitalization. New York; Montreal, Holt Rinehart and Winston.

Knudson, T. (2003). Grassy Narrows: McClatchy paper and Abitibi. Sacramento Bee. Sacramento.

macho. (2005). "Forestry hacks point to "consultation process" with pride." from http://friendsofgrassynarrows.com/item.php?283F.

Page, S. E. (2009). Understanding complexity, The Teaching Company.

Roberge, R. (2002). "The state of the art: Aboriginal policy research in Canada." Horizons 6(1).

Shiell, L. (1990). "Native Renaissance." Canadian Geographic Aug(Sept): 60-66.

Shkilnyk, A. M. (1985). A Poison Stronger than Love: The Destruction of an Ojibwa Community. New Haven, Yale University Press.

Sultzman, L. (2000). "Ojibwa history." from www.tolatsga.org/ojib.html. 
Tabar, T. (2005, April 26, 2005). "Not all blockades are bad: A Palestinian on Canadian indigeous resistance." Retrieved April 27, 2005, from http://friendsofgrassynarrows.com/item.php?306F.

Teevan, J. J. and W. E. Hewitt, Eds. (2005). Introduction to sociology: A Canadian focus. Toronto, Pearson Prentice Hall.

Wallace, A. F. C. (1956). "Revitalization Movements in Development." American Anthropologist 58: 264-281.

Wallace, A. F. C. (1972(1969)). The death and rebirth of the Senaca. New York, Vantage.

Warren, W. W. (1984(1885)). History of the Ojibways, based upon traditions and oral statements. St. Paul, Minnesota, Minnesota Historical society Press.

Wolfram, S. (2002). A New Kind of Science, Wolfram Media.

Young, F. W. and R. C. Young (1973). Comparative Studies of Community Growth. Morgantown, W.Va, West Virginia University. 